\title{
Oral ingestion of lactic-acid bacteria by rats increases lymphocyte proliferation and interferon- $\gamma$ production
}

\author{
Najat Aattouri ${ }^{1,2} *$, Mohammed Bouras ${ }^{1}$, Daniel Tome ${ }^{1}$, Ascension Marcos ${ }^{3}$ and Daniel Lemonnier ${ }^{2}$ \\ ${ }^{1}$ INRA, Laboratoire de Nutrition Humaine et de Physiologie Intestinale, Institut National Agronomique Paris-Grignon, \\ F-75231 Paris, France \\ ${ }^{2}$ Groupe de Recherche en Pédiatrie de Normandie, CHU Charles Nicolle, F-76031 Rouen, France \\ ${ }^{3}$ Instituto de Nutrition y Bromatologia, Facultad de Pharmacia, Ciudad Universitaria, 28040 Madrid, Spain
}

(Received 27 September 2001 - Accepted 3 December 2001)

\begin{abstract}
The effect of feeding lactic-acid bacteria on indices of functions of lymphocytes obtained from Peyer's patches, peripheral blood and spleen from inbred Wistar-Furth rats were studied. Rats were fed on purified diets supplemented with $350 \mathrm{~g}$ milk or yoghurt $/ \mathrm{kg}$ diet for 4 weeks. At the end of the feeding period, immune cells from the three sites were isolated and proliferation, interferon- $\gamma$ production and lymphocyte subset composition were studied. Rats consuming yoghurt had a greater in vitro proliferative response to yoghurt bacteria in the three lymphoid compartments, a greater interferon- $\gamma$ production in response to bacteria and concanavalin $\mathrm{A}$ in Peyer's patches and spleen, and a greater number of Peyer's patches B lymphocytes than milkfed rats. Macrophage and T lymphocyte proportions and lymphocyte subset composition in the three sites were unaffected by yoghurt. These results indicate that feeding live bacteria contained in yoghurt may interact with the intestinal immune system, and influence the systemic immune system.
\end{abstract}

Lactic-acid bacteria: Intestinal and systemic immunity: Interferon: Rats

It is known that when an antigen enters the body through the oral route, the first response that normally occurs, through intra-epithelial lymphocytes of the small intestine, is tolerance. When tolerance is abrogated an immune response is produced. The antigen is transported into Peyer's patches (PP) and presented to T cells by dendritic cells or macrophages, and $\mathrm{T}$ cells then present the antigen to B cells. These activated lymphocytes pass to the mesenteric lymph nodes through the thoracic duct and circulate in the bloodstream from where they can be distributed to the intestinal lamina propria and to lymphoid organs such as the spleen (Nagata et al. 2000; Weiner, 2000). Thus, the stimulation of the immune system involves activation of immunocompetent cells: macrophages, $\mathrm{T}$ lymphocytes $(\mathrm{T}$ helper (cluster determinant (CD)4+) and $\mathrm{T}$ cytotoxicsuppressor cells (CD8+))and B lymphocytes, their proliferation and production of cytokines. Cytokines are autocrine-, paracrine-, and endocrine-regulatory glycoproteins that interact with specific cell receptors and have pleiotropic effects. They affect both the activation state, proliferation, maturation, and function of cells from the immune system, as well as cell functions in major organs (Cavaillon, 1996). Interferon (IFN)- $\gamma$ is an essential cytokine in immune reactions (Trinchieri \& Perussia, 1985).

Studies in healthy volunteers have shown that ingestion of yoghurt containing live bacteria effectively elevates 2$5 \mathrm{~A}$ synthetase activity in blood mononuclear cells (BMC) (Solis \& Lemonnier, 1991; Aattouri \& Lemonnier, 1997), an enzyme induced by IFN and considered to play an important role in their action (Samuel, 1991). In vitro, human BMC produce IFN- $\gamma$ and other cytokines when incubated with lactic-acid bacteria, in particular those used for yoghurt processing (Solis \& Lemonnier, 1993). Studies in the mice have suggested that feeding fermented milk or lactic-acid bacteria may affect the immune system (for review, see Meydani \& Ha, 2000), for example modify macrophage phagocytosis (Perdigon et al. 1988) and immunoglobulin (i.e. immunoglobulin (Ig) G-2a) secretion (Conge et al. 1980). Such functions can be controlled by IFN- $\gamma$ (Street \& Mosmann, 1991; Murray, 1990). Recently, Gill et al. (2000) have observed that spleen cells from mice

\footnotetext{
Abbreviations: BMC, blood mononuclear cells; CD, cluster determinant; Con A, concanavalin A; IFN, interferon; Ig, immunoglobulin; PP, Peyer's patches. * Corresponding author: Dr Najat Aattouri, present address STELLA, FSSA Pavillon Paul-comtois, local 1316, Université Laval, G1K 7P4, Québec, Canada, fax +1 41865939 25, email aattouri@aln.ulaval.ca
} 
fed lactic-acid bacteria, produce higher amounts of IFN- $\gamma$ in response to stimulation with concanavalin $\mathrm{A}$ (Con A) than cells from control mice. However, the role of lymphoid organs in the production of IFN- $\gamma$ in response to these bacteria or to fermented milk has not been investigated in relation to immune blood cells. To evaluate the possible effects of feeding fermented milk, we studied the production of IFN- $\gamma$ by cells from PP, spleen and blood, as well as the proliferation of cells from these organs and their number of immune cells.

\section{Materials and methods}

\section{Animals and diets}

Specific pathogen-free inbred female Wistar-Furth rats (4-week-old) were obtained from Iffa-Credo (L'Arbresle, France) and housed in transparent plastic cages with stainless-steel wire lids (four rats per cage). The rats were maintained at $21 \pm 1{ }^{\circ} \mathrm{C}$ and $60-80 \%$ relative humidity, with a $12 \mathrm{~h}$ light-dark cycle. After feeding for 2 weeks on a basal diet, rats were subdivided at random into two groups and fed the basal diet for 4 weeks (Table 1) (Potier de Courcy et al. 1989) supplemented with $350 \mathrm{~g}$ milk or yoghurt $/ \mathrm{kg}$ diet. The mixture was prepared just before distribution every $2 \mathrm{~d}$. The rats were given free access to food and water. Yoghurt (total number of bacteria in the yoghurt was $2 \times 10^{7}$ bacteria/ml) and milk were obtained from the Centre de Recherche International Daniel Carasso (Le Plessis Robinson, France) in liquid form (Table 2). All procedures were in accordance with the Institute's guide for the care and use of laboratory animals.

\section{Bacterial strain}

Lactobacillus bulgaricus, Streptococcus thermophilus (strains 100158 and 001158 respectively) were used for in vitro studies and for yoghurt processing, yoghurt being a milk fermented by these two symbiotic species and containing abundant numbers of viable lactic-acid bacteria,

Table 1. Composition of the basal diet used

\begin{tabular}{lc}
\hline Ingredient & Level in the diet $(\mathrm{g} / \mathrm{kg})$ \\
\hline Casein & 140 \\
DL-Methionine & 1 \\
Cellulose & 20 \\
Peanut oil & 25 \\
Rapeseed oil & 25 \\
Sucrose-starch (1:3, w/w) & 734 \\
Mineral mixture* & 45 \\
Vitamin mixture† & 10
\end{tabular}

* Mineral mixture (g/kg): $\mathrm{CaHPO}_{4} \cdot 2 \mathrm{H}_{2} \mathrm{O} 380, \mathrm{~K}_{2} \mathrm{HPO}_{4} 240, \mathrm{CaCO}_{3} 180$, $\mathrm{MgSO}_{4} .7 \mathrm{H}_{2} \mathrm{O} 90, \mathrm{NaCl} 69, \mathrm{MgO} 20, \mathrm{FeSO}_{4} .7 \mathrm{H}_{2} \mathrm{O} 8.6, \mathrm{ZnSO}_{4} \cdot \mathrm{H}_{2} \mathrm{O} 5$, $\mathrm{MnSO}_{4} \cdot \mathrm{H}_{2} \mathrm{O} 5, \mathrm{CuSO}_{4} \cdot 5 \mathrm{H}_{2} \mathrm{O} 1, \mathrm{NaF} 0.8, \mathrm{CrK}\left(\mathrm{SO}_{4}\right)_{2} \cdot 12 \mathrm{H}_{2} \mathrm{O} 0.50, \mathrm{KI} 0.04$, $\left(\mathrm{NH}_{4}\right)_{6} \mathrm{Mo}_{7} \mathrm{O}_{2} \cdot 4 \mathrm{H}_{2} \mathrm{O} 0.02, \mathrm{CoCO}_{3} 0.02, \mathrm{Na}_{2} \mathrm{SeO}_{3} 0.02$.

† Vitamin mixture $(\mathrm{mg} / \mathrm{kg})$ : retinyl acetate 150 , cholecalciferol 62.5 , tocopherol acetate 5000 , menadione 100 , thiamin $\mathrm{HCl} 1000$, riboflavin 1000 , niacin 4500, D-pantothenate $\mathrm{Ca} 3000$, pyridoxine $\mathrm{HCl} 1000$, inositol 5000 , D-biotin 20, folic acid 200, cyanocobalamin 1.35 , ascorbic acid 10000 , para-aminobenzoic acid 5000, choline chloride 75000 . Sucrose was added to a total of $1 \mathrm{~kg}$.
Table 2. Composition of milk and yoghurt used

\begin{tabular}{lcc}
\hline Ingredient & Milk & Yoghurt \\
\hline Protein $(\mathrm{g} / \mathrm{kg})$ & 34 & 34 \\
Carbohydrate $(\mathrm{g} / \mathrm{kg})$ & 45 & 36 \\
Lipid $(\mathrm{g} / \mathrm{kg})$ & 50 & 46 \\
Energy $(\mathrm{MJ} / \mathrm{kg})$ & $3 \cdot 10$ & $3 \cdot 08$ \\
Chlorine $(\mathrm{mmol} / \mathrm{kg})$ & 27 & 38 \\
Sodium $(\mathrm{mmol} / \mathrm{kg})$ & 10 & 20 \\
Potassium $(\mathrm{mmol} / \mathrm{kg})$ & 39 & 49 \\
Magnesium $(\mathrm{mmol} / \mathrm{kg})$ & $2 \cdot 8$ & $5 \cdot 7$ \\
Calcium $(\mathrm{mmol} / \mathrm{kg})$ & 31 & 41 \\
\hline
\end{tabular}

and in vitro studies. Strains were provided by the Centre de Recherche International Daniel Carasso. For in vitro studies bacteria were cultured in Manose-RugoseSharpe medium, in separate cultures, and were washed three times with RPMI 1640 medium (Gibco, Cergy Pontoise, France) without antibiotics and without fetal calf serum before use.

\section{Preparation of cellular suspensions}

All procedures were performed under aseptic conditions. The rats were anaesthetised with $40 \mathrm{mg}$ pentobarbital $/ \mathrm{kg}$ (Sanofi, Paris, France).

Peripheral blood. Blood $(10 \mathrm{ml})$ was withdrawn from the abdominal aorta into a heparinised syringe. The BMC fraction was obtained by density gradient centrifugation on Ficoll Hypaque (Pharmacia Biotech, Orsay, France) (Boyum, 1968). BMC were washed with RPMI 1640 (Gibco) supplemented with fetal calf serum $(50 \mathrm{ml} / \mathrm{l})$ (Gibco) and $100 \mu \mathrm{g}$ gentamicin/ml (Gibco); this medium was used in all experiments unless otherwise indicated. The red blood cells were removed by incubating BMC for $8 \mathrm{~min}$ with $0 \cdot 16 \mathrm{M}-\mathrm{NH}_{4} \mathrm{Cl}$ in ice and washed twice with medium.

Spleen cells. The spleen was removed from each rat and placed in sterile Petri dishes in medium, passed through a cell strainer (Falcon, Paris, France), red blood cells were removed by the same method as used for BMC. Then, the cells were washed twice with medium.

Peyer's patches. All PP were carefully excised from the whole length of the small intestine, removed and transferred to Petri dishes containing medium. PP were slit by a surgical blade and teased gently. The cellular suspensions were passed through a cell strainer and then through a sterilised gauze band to remove cell debris and washed twice with medium. Cells were counted at the end of the preparation of cellular suspensions, and the proportion of viable cells was determined by Trypan Blue exclusion before culture.

\section{Proliferation assays}

A single-cellular suspension of BMC, spleen cells or PP cells was incubated in a flat bottom, ninety-six-well culture plate (Falcon) at $2 \times 10^{5}$ cells/well in complete medium (RPMI 1640 (Gibco) supplemented with fetal calf serum (100 ml/l), 2 mM-L-glutamine, $100 \mathrm{U}$ penicillin/ml, $100 \mu \mathrm{g}$ 
streptomycin/ml, $5 \times 10^{-5}$ M-2-mercaptoethanol and $100 \mu \mathrm{g}$ gentamicin/ml). Triplicate wells were challenged with a dose of $2 \times 10^{3}, 2 \times 10^{4}, 2 \times 10^{5}$ or $2 \times 10^{6}$ bacteria/well for $48 \mathrm{~h}$. The cells were pulsed with $27.7 \times 10^{4}$ $\mathrm{Bq}\left[6-{ }^{3} \mathrm{H}\right]$ thymidine (specific activity $185 \mathrm{GBq} / \mathrm{mmol}$; Amersham, Les Ulis, France) in a volume of $20 \mu \mathrm{l}$ per well. The cells were harvested on glass filter paper $18 \mathrm{~h}$ later and the incorporation of $\left[{ }^{3} \mathrm{H}\right]$ thymidine into DNA was measured with an Inotech counter (Automatic filter counting system IBN-384, Dottikon, Switzerland). Several concentrations of Con A were tested from 1 to $10 \mu \mathrm{g} / \mathrm{ml}$, to determine an optimal concentration (Fig. 1).
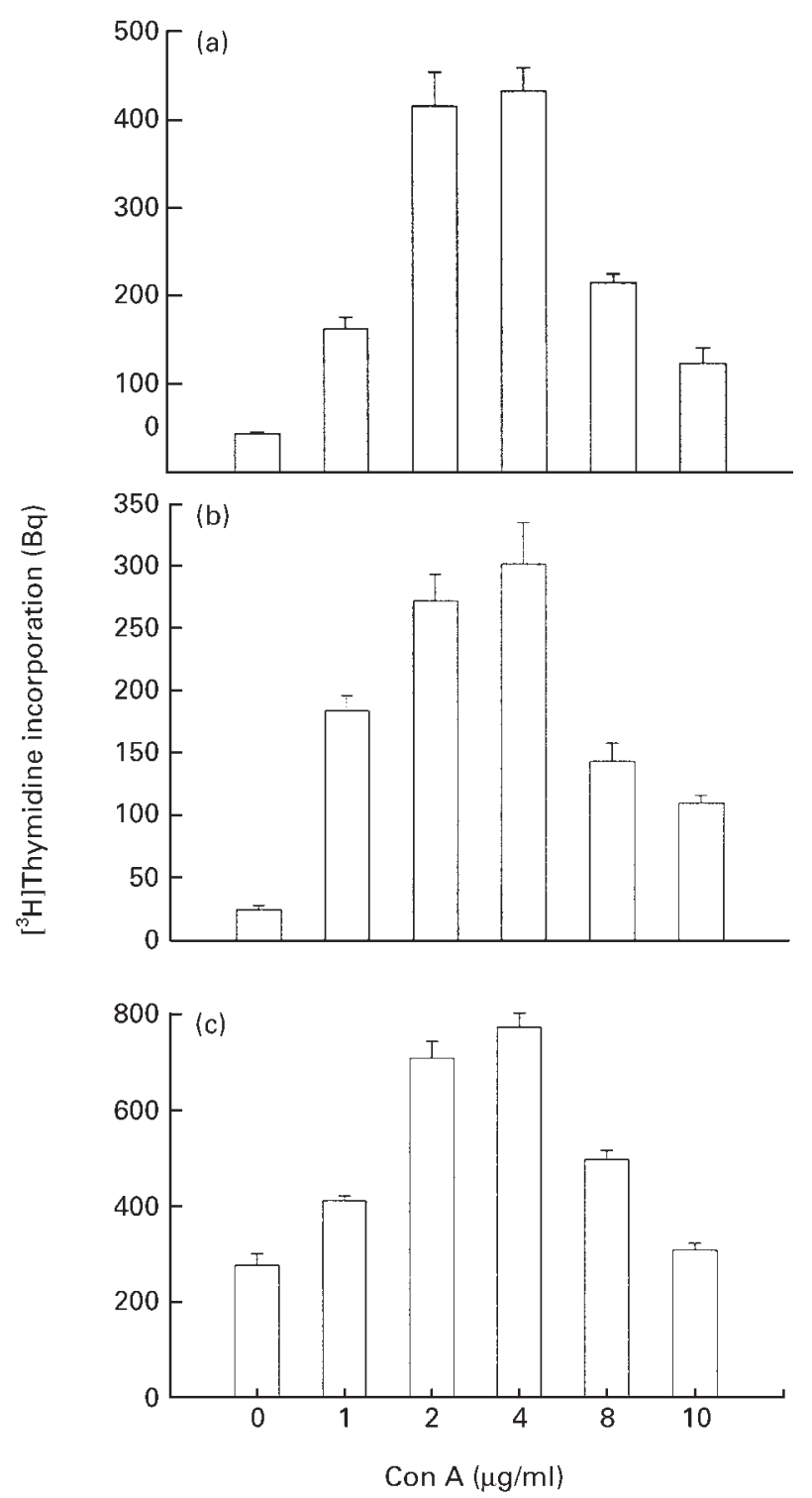

Fig. 1. Determination of optimal concanavalin $A(C o n A)$ concentration: proliferative response of (a) Peyer's patches cells, (b) blood mononuclear cells and (c) spleen cells to Con A. Cells were obtained from rats fed basal diet. They were incubated $(2 \times$ $10^{6} \mathrm{cells} / \mathrm{ml}$ ) with different quantities of Con A for $48 \mathrm{~h}$ and pulsed with $\left[{ }^{3} \mathrm{H}\right]$ thymidine. For details of diet and procedures, see Table 1 and $p .368$. Values are means for four rats per group with standard errors shown by vertical bars.
Determination of optimal in vitro conditions of interferon$\gamma$ production

To determine the optimal conditions for IFN- $\gamma$ production, two concentrations of cells $\left(1 \times 10^{6}\right.$ and $2 \times 10^{6}$ cells $\left./ \mathrm{ml}\right)$ were incubated for 24 or $48 \mathrm{~h}$ with different concentrations of bacteria $\left(2 \times 10^{4}, 2 \times 10^{5}, 2 \times 10^{6}\right.$ or $2 \times 10^{7}$ bacteria/ $\mathrm{ml}$ ). The optimal production of IFN- $\gamma$ was obtained with $2 \times 10^{5}$ bacteria/ml in the case of BMC and PP and spleen cells, when incubated for $48 \mathrm{~h}$. Thus, on the basis of these results, the following conditions were kept in all subsequent experiments: $2 \times 10^{6} \mathrm{cell} / \mathrm{ml}, 2 \times 10^{5}$ bacteria/ $\mathrm{ml}$ and incubation time $48 \mathrm{~h}$.

\section{Cell cultures}

BMC, spleen cells or PP cells $\left(100 \mu \mathrm{l} ; 1 \times 10^{6}\right.$ and $\left.2 \times 10^{6} / \mathrm{ml}\right)$ were cultured in a total volume of $200 \mu \mathrm{l}$ in ninety-six-well plates in complete medium. Single-cell suspensions were incubated with several densities of bacteria (Lactobacillus bulgaricus and Streptococcus thermophilus (1:1), over a range of $2 \times 10^{4}$ to $\left.2000 \times 10^{4}\right)$. Cultures were incubated for $48 \mathrm{~h}$ at $37^{\circ} \mathrm{C}$ in air $-\mathrm{CO}_{2}(95: 5, \mathrm{v} / \mathrm{v})$, with either bacterial mixture or $2 \mu \mathrm{g}$ Con $\mathrm{A} / \mathrm{ml}$ (optimal concentration). At the end of the incubations, cell-free supernatant fractions were obtained and stored at $-80^{\circ} \mathrm{C}$ until assayed for IFN- $\gamma$.

\section{Interferon- $\gamma$ assays}

Interferon- $\gamma$ concentration was determined by ELISA using a kit from Holland Biotechnology (ref. 13281-019; Life Technologie, Paris, France) according to the manufacturer's instructions. A linear dose-response curve was obtained between 250 and $10000 \mathrm{pg} / \mathrm{ml}$. The intra-assay CV was $8.5 \%$, the inter-assay CV was $11.9 \%$.

\section{Fluorescence staining and flow cytometric analysis}

The expression of cell surface markers was investigated by indirect immunofluorescence. Briefly, BMC, spleen cells or $\mathrm{PP}$ cells $\left(10^{6}\right.$ cells $\left./ \mathrm{ml}\right)$ were incubated with mouse monoclonal antibodies to characterise B lymphocytes (OX12, mouse IgG2a antibody to rat $\kappa$ light chain; $0.6 \mu \mathrm{g} /$ $10^{6}$ cells), T cytotoxic-suppressor (OX8, mouse IgG1 anti-CD8; $0.4 \mu \mathrm{g} / 10^{6}$ cells) and macrophages - monocytes (ED1, mouse IgG1, anti-CD68; $0 \cdot 2 \mu \mathrm{g} / 10^{6}$ cells) for $1 \mathrm{~h}$ at $4^{\circ} \mathrm{C}$. Analysis of each cell suspension included an isotype negative control in which cells were incubated with mouse $\operatorname{IgG} 2 \mathrm{a}\left(\mathrm{F} 10-89-4 ; 0 \cdot 2 \mu \mathrm{g} / 10^{6}\right.$ cells) or mouse IgG1 (F8-11-13; $0.5 \mu \mathrm{g} / 10^{6}$ cells). After two washings with PBS supplemented with $50 \mathrm{ml}$ fetal calf serum/l and $15 \mathrm{mmol}$ sodium azide/l, the cells were treated for $30 \mathrm{~min}$ at $4^{\circ} \mathrm{C}$, with $\mathrm{F}\left(\mathrm{ab}^{\prime}\right)_{2}$ rabbit anti-mouse IgG R-phycoerythrin conjugate $\left(10 \mu \mathrm{g} / 10^{6}\right.$ cells $)$ in the case of staining $\mathrm{B}$ lymphocytes and macrophages-monocytes, and with streptavidin conjugated to R-phycoerythrin in the case of staining $\mathrm{T}$ cytotoxic-suppressor. To stain $\mathrm{T}$ lymphocytes and $\mathrm{T}$ helper cells, a direct assay with a phycoerythrin-conjugated mouse anti-rat IG (OX19, mouse IgG1, anti-CD5; $10 \mu \mathrm{g}$ / $10^{6}$ cells) and a fluorescein isothiocyanate-conjugated 
mouse anti-rat immunoglobulin (W3/25, mouse IgG1, antiCD4; $0.5 \mu \mathrm{g} / 10^{6}$ cells), were used respectively. Fluorescein isothiocyanate-conjugated mouse $\operatorname{IgG} 1\left(2 \mu \mathrm{g} / 10^{6}\right.$ cells $)$ or phycoerythrin-conjugated mouse IgG1 (10 $\mu \mathrm{g} / 10^{6}$ cells) were used as negative controls for direct assay. Cells were incubated for $30 \mathrm{~min}$ at $4^{\circ} \mathrm{C}$ and washed twice. As indicated earlier, the antibodies used were able to identify differentiated cells, however, unlabelled cells (undifferentiated cells) that could not be reacted with the used antibodies remained unidentified and thus could not be counted.

The stained surfaces were fixed in paraformaldehyde $(10 \mathrm{ml} / \mathrm{l})$ and analysed in a FACScan flow cytometer (Becton Dickinson, Le Pont de Claix, France). All antibodies were purchased from Serotec (Oxford, Oxon., UK).

\section{Statistics}

Data were analysed by ANOVA or $t$ test using the procedures of Statistical Analysis Systems, version 6.03 (SAS Institute Inc., Cary, NC, USA). $P<0.05$ was taken to indicate statistical significance. The results are reported as mean values with their standard errors.

\section{Results}

Rats fed for 4 weeks on either milk- or yoghurt-supplemented diets consumed the same amount of food (19 (SEM 0.35) g/d). As calculated from the composition of the diet, the rats fed yoghurt consumed about $1.4 \times 10^{9}$ bacteria/d. Weight gain was not significantly different between the two groups (3.25 (SEM 0.17) g/d).

\section{Lymphoid cell surface markers}

BMC, spleen cells and PP cells isolated from rats fed for 4 weeks on either milk- or yoghurt-supplemented diets were first analysed for surface markers of lymphoid cells, i.e. B lymphocytes, $\mathrm{T}$ lymphocytes, $\mathrm{T}$ lymphocyte subsets and monocyte-macrophage cells. The number of cells per PP was significantly higher in the yoghurt-supplemented group than in the milk-supplemented group $(P<0 \cdot 05)$. The increase in cell number was entirely explained by a significant $(P<0.05)$ increase in the number of B lymphocytes from $24.0 \times 10^{6}\left(\mathrm{SEM} 0.9 \times 10^{6}\right)$ in rats fed milk to $33.0 \times 10^{6}\left(\mathrm{SEM} 2.6 \times 10^{6}\right)$ in rats fed yoghurt. The proportions of the other cell types in PP were unaffected by the consumption of yoghurt. No significant changes were detected in the number of cells per spleen and in the proportions of the spleen and blood lymphocytes, lymphocyte subsets and macrophages-monocytes between the two groups (Table 3).

\section{In vitro proliferation of blood mononuclear cells, spleen cells and Peyer's patches cells}

Cells isolated from blood, spleen and PP of rats fed for 4 weeks either with milk- or yoghurt-supplemented diets were incubated in vitro in the presence of Con A or lactic-acid bacteria, and their capacity to proliferate measured as the incorporation of $\left[{ }^{3} \mathrm{H}\right]$ thymidine after $48 \mathrm{~h}$ incubation. Lymphocytes from the two groups proliferate in response to Con $\mathrm{A}$, this response was greater for cells from rats fed the yoghurt diet (Table 4). As shown in Fig. 2, lymphocytes from rats fed the milk-supplemented diet did not proliferate in response to bacteria. Feeding yoghurt for 4 weeks significantly increased the proliferative response of BMC, spleen cells and PP cells to the lactic-acid bacteria. An optimal effect was obtained for $2 \times$ $10^{5}$ or $2 \times 10^{6}$ bacteria/ml: cell proliferation was increased 122-, 43- and 21-fold for spleen, PP and blood cells respectively $(P<0.001$ for each tissue).

\section{In vitro production of interferon- $\gamma$ by blood mononuclear cells, spleen cells and Peyer's patches cells}

$\mathrm{BMC}$, spleen cells and PP cells from the rats fed for 4 weeks either with the milk- or yoghurt-supplemented diets were incubated in vitro in the presence of either lactic-acid bacteria or a mitogen (Con A), and the concentrations of IFN- $\gamma$ in the supernatant fractions of the culture media measured by ELISA.

Table 3. Effect of feeding rats with yoghurt $v$. milk on the proportion of immune cells $\dagger$ (Mean values with their standard errors for four rats per group)

\begin{tabular}{|c|c|c|c|c|c|c|c|c|c|c|c|}
\hline & \multirow[b]{3}{*}{ Group } & \multicolumn{10}{|c|}{ Cells labelled (\%)‡ } \\
\hline & & \multicolumn{2}{|c|}{ B lymphocytes } & \multicolumn{2}{|c|}{ T Iymphocytes } & \multicolumn{2}{|c|}{$\begin{array}{c}\text { T helper } \\
\text { lymphocytes }\end{array}$} & \multicolumn{2}{|c|}{$\begin{array}{l}\text { T cytotoxic- } \\
\text { suppressor } \\
\text { lymphocytes }\end{array}$} & \multicolumn{2}{|c|}{$\begin{array}{c}\text { Macrophages- } \\
\text { monocytes }\end{array}$} \\
\hline & & Mean & SEM & Mean & SEM & Mean & SEM & Mean & SEM & Mean & SEM \\
\hline \multirow[t]{2}{*}{ Peyer's patches } & Milk & $59 \cdot 8$ & 1.5 & $16 \cdot 5$ & $1 \cdot 1$ & $14 \cdot 1$ & $1 \cdot 1$ & 4.5 & 1.5 & 3.0 & 0.7 \\
\hline & Yoghurt & $81 \cdot 8^{\star \star \star}$ & 3.3 & $17 \cdot 7$ & $1 \cdot 1$ & $15 \cdot 1$ & 1.4 & $5 \cdot 0$ & 0.7 & 3.5 & 1.5 \\
\hline \multirow[t]{2}{*}{ Blood } & Milk & $19 \cdot 0$ & 2.6 & 68.5 & 2.5 & $54 \cdot 0$ & 2.6 & 23.5 & $2 \cdot 2$ & 3.7 & $1 \cdot 3$ \\
\hline & Yoghurt & $20 \cdot 8$ & 2.9 & 71.9 & $1 \cdot 2$ & 55.9 & 1.9 & $23 \cdot 6$ & $2 \cdot 8$ & $4 \cdot 4$ & 1.4 \\
\hline \multirow[t]{2}{*}{ Spleen } & Milk & $43 \cdot 6$ & 2.6 & $42 \cdot 6$ & 3.6 & $37 \cdot 0$ & 2.7 & $19 \cdot 5$ & $2 \cdot 3$ & $4 \cdot 0$ & 0.6 \\
\hline & Yoghurt & $44 \cdot 0$ & 4.5 & $43 \cdot 1$ & 3.5 & $37 \cdot 8$ & 4.4 & $17 \cdot 8$ & 1.0 & 4.0 & 0.7 \\
\hline
\end{tabular}

†For details of diets and procedures, see Tables 1 and 2 and p. 368.

$\ddagger$ The percentage of cells labelled was determined by indirect and direct immunofluorescence B lymphocytes (B), cytotoxic-suppressor lymphocytes (CD8) monocytes-macrophages (CD68) and T lymphocytes (CD5) helper lymphocytes (CD4) respectively.

Mean value was significantly different from those of the milk group: ${ }^{\star \star \star} P<0.001$. 
Table 4. Effect of feeding rats with yoghurt $v$. milk on the in vitro proliferative response to concanavalin A†‡

(Mean values with their standard errors for eight rats per group)

\begin{tabular}{|c|c|c|c|c|c|}
\hline & \multirow[b]{3}{*}{ Group } & \multicolumn{4}{|c|}{$\left[{ }^{3} \mathrm{H}\right]$ Thymidine incorporation $(\mathrm{Bq}) \ddagger$} \\
\hline & & \multicolumn{2}{|c|}{ Cell alone } & \multicolumn{2}{|c|}{ Con A $(2 \mu \mathrm{g} / \mathrm{ml})$} \\
\hline & & Mean & SEM & Mean & SEM \\
\hline \multirow[t]{2}{*}{ Peyer's patches } & Milk & 43 & 3 & 465 & 21 \\
\hline & Yoghurt & 40 & 5 & $1675^{\star \star \star}$ & 75 \\
\hline \multirow[t]{2}{*}{ Blood } & Milk & 21 & 2 & 224 & 13 \\
\hline & Yoghurt & 24 & 6 & $876^{\star \star \star}$ & 49 \\
\hline \multirow[t]{2}{*}{ Spleen } & Milk & 141 & 11 & 657 & 55 \\
\hline & Yoghurt & 138 & 7 & $14651^{\star \star \star}$ & 134 \\
\hline
\end{tabular}

†For details of diets and procedures, see Tables 1 and 2 and p. 368.

$\ddagger$ Cells were obtained from rats fed on diets enriched with milk or yoghurt for 4 weeks. They were incubated $\left(2 \times 10^{6}\right.$ cells $\left./ \mathrm{ml}\right)$ with Con $A$ for $48 \mathrm{~h}$ and pulsed with $\left[{ }^{3} \mathrm{H}\right]$ thymidine. Con $\mathrm{A}$, concanavalin $\mathrm{A}$.

Mean values were significantly different from those of the milk-fed groups: ${ }^{\star \star \star} P<0.05$.

IFN- $\gamma$ was not detected in supernatant fraction cells incubated in absence of bacteria or of Con A. In contrast, a high production of IFN- $\gamma$ was observed in presence of bacteria or Con A in both groups of rats. Comparison between the two groups (milk and yoghurt) showed that IFN- $\gamma$ production in the yoghurt group was doubled after mitogen or bacterial stimulation in both spleen cells and PP cells. However, results obtained from BMC did not reveal any diet effect of diet on IFN- $\gamma$ production (Table 5).

\section{Discussion}

Our results demonstrate that a stimulatory effect on intestinal and systemic immune functions is observed when rats are fed a diet containing the live lactic-acid bacteria of yoghurt compared with a diet enriched with milk. This significant effect was characterised by a higher proliferative response of lymphocytes from the PP, the spleen and blood, by an elevated production of IFN- $\gamma$ from the PP and spleen cells, and by a greater number of PP B lymphocytes. This work also shows rat cells studied ex vivo have a similar response to that previously obtained with mouse and human cells (Solis \& Lemonnier, 1991, 1993; Muscettola et al. 1994; Aattouri \& Lemonnier, 1997) and that rats are a convenient animal model allowing studies of immune functions of PP.

The milk used to prepare yoghurt, and the milk used for the milk-enriched diet, came from the same batch, thus the differences observed between the two groups of rats are due to the presence of bacteria in the yoghurt or/and to the fermentation process which might have generated active products. We believe that it is the bacteria which are responsible for the observed effects: in our in vitro experiments they stimulated cell proliferation as well as the production of IFN- $\gamma$. It has also been shown that IFN- $\gamma$ induction is attributable to bacterial cell walls (Solis \& Lemonnier, 1993). Muramyl dipeptide, a fragment of peptidoglycans (the major component of lactic-acid bacteria cell wall), stimulates the production of IFN- $\gamma$ by CD4+ lymphocytes (Aattouri \& Lemonnier, 1997). In addition, orally administered muramyl peptide can induce

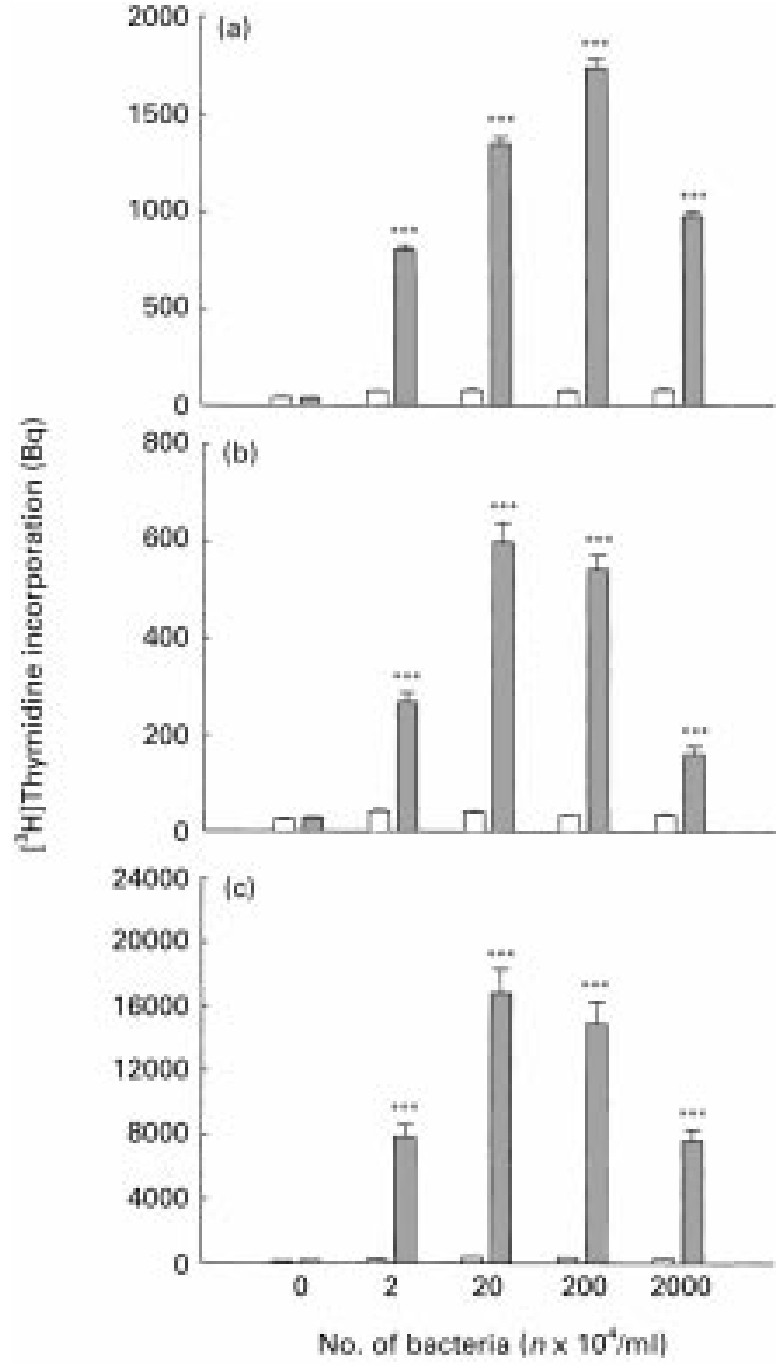

Fig. 2. Effect of feeding rats with milk $v$. yoghurt on the proliferative response, proliferative response of (a) Peyer's patches cells, (b) blood mononuclear cells and (c) spleen cells to the lactic bacteria Streptococcus thermophilus and Lactobacillus bulgaricus (1:1) Cells were obtained from rats fed on diets enriched with milk $(\square)$ or yoghurt $(\mathbb{Q})$ for 4 weeks. They were incubated $\left(2 \times 10^{6}\right.$ cells $\left./ \mathrm{ml}\right)$ with different quantities of bacteria for $48 \mathrm{~h}$ and pulsed with $\left[{ }^{3} \mathrm{H}\right]$ thymidine. Optimal concentrations were determined to be $20 \times 10^{4}$ and $200 \times 10^{4}$ bacteria $/ \mathrm{ml}$. For details of diets and procedures, see Tables 1 and 2 and p. 368. Values are means for eight rats per group with standard errors shown by vertical bars. Mean values were significantly different from the milk-fed group at each concentration of bacteria added in the media: ${ }^{* \star *} P<0.001$.

endogenous cytokines (Okutomi et al. 1990). Thus, lactic-acid bacteria, which are sensitive to lysozyme digestion, may liberate peptidoglycan fragments in situ, which can then induce immunomodulating effects at the intestinal level.

Lactic-acid bacteria enter the host's body through the feeding process. It is known that lactic-acid bacteria are able to be in contact with the immune system of the gutassociated lymphoreticular tissue, which is largely represented by the PP. Ingested antigens are known to be first taken up by active pinocytic cells, i.e. $\mathrm{M}$ cells, which cover the dome region of $\mathrm{PP}$, and are then delivered to 
Table 5. Effect of feeding yoghurt $v$. milk on in vitro interferon- $\gamma$ production†‡ (Mean values with their standard errors for eight rats per group)

\begin{tabular}{|c|c|c|c|c|c|c|}
\hline & \multirow[b]{3}{*}{ Group } & \multicolumn{5}{|c|}{ Interferon- $\gamma$ concentrations (pg/ml) } \\
\hline & & \multirow[b]{2}{*}{ Cells alone } & \multicolumn{2}{|c|}{$\begin{array}{l}\text { Lactic bacteria } \\
\qquad\left(2 \times 10^{5}\right)\end{array}$} & \multicolumn{2}{|c|}{ Con A $(2 \mu \mathrm{g} / \mathrm{ml})$} \\
\hline & & & Mean & SEM & Mean & SEM \\
\hline \multirow[t]{2}{*}{ Peyer's patches } & Milk & ND & 329 & 57 & 741 & 50 \\
\hline & Yoghurt & ND & $731^{\star \star \star}$ & 77 & $1464^{\star \star \star}$ & 170 \\
\hline \multirow[t]{2}{*}{ Blood } & Milk & ND & 3772 & 899 & 5177 & 1228 \\
\hline & Yoghurt & ND & 4170 & 1102 & 5640 & 1027 \\
\hline \multirow[t]{2}{*}{ Spleen } & Milk & ND & 11110 & 1619 & 13966 & 2027 \\
\hline & Yoghurt & ND & $26692^{*}$ & 7364 & $28051^{*}$ & 6014 \\
\hline
\end{tabular}

ND, not detected.

Mean values were significantly different from those of the milk-fed groups: ${ }^{\star} P<0.05,{ }^{\star \star \star} P<0.001$.

†For details of diets and procedures, see Tables 1 and 2 and p. 368.

$\mp$ In vitro production of interferon- $\gamma$ by $2 \times 10^{6} \mathrm{cells} / \mathrm{ml}$ in different sites after $48 \mathrm{~h}$ incubation in the presence of either $2 \times 10^{5}$ cells $/ \mathrm{ml}$ lactic bacteria or Con A, from rats fed on diets enriched with milk or yoghurt for 4 weeks.

their underlying T and B cell zones (Bienestock \& Befus, 1980; Neutra et al. 1987). Thus, bacteria and their walls are generally presented to $\mathrm{M}$ cells and then to lymphocytes, whether the bacteria were still viable or whether they were killed in the digestive tract. Indeed, these lymphocytes obtained from rats fed yoghurt, when incubated in presence of lactic-acid bacteria, produced high levels of IFN- $\gamma$ and demonstrated an enhanced proliferative response. Thus, these cells have been sensitised by the bacteria contained in yoghurt, a mechanism that may lead to an enhanced production of IFN- $\gamma$ by T and natural killer cells (Lefèvre $e t$ al. 1996). Interferon- $\gamma$ is known to stimulate the production of interleukin 2 which is involved in B and T lymphocyte proliferation (Nakanishi et al. 1992). Thus, IFN- $\gamma$ could be implicated in this in increased proliferative response to bacteria. The higher number of B lymphocytes observed in the $\mathrm{PP}$ of rat fed lactic-acid bacteria may be in accordance with a greater in vivo proliferative process.

Lymphocytes from PP are known to be released from the intestine to reach the systemic circulation (Guy-Grand et al. 1978; Ruedl et al. 1993) and the effects of antigen feeding on this phenomenon are documented (Mowat, 1987). In rats that were fed lactic-acid bacteria, proliferation of blood and spleen lymphocytes was higher in vitro when incubated in presence of lactic-acid bacteria. Thus, the circulating activated cells from the PP could explain the higher proliferative response observed in the spleen and in the blood of lactic-acid bacteria-fed rats.

The diet containing lactic-acid bacteria did not induce any change in IFN- $\gamma$ production by BMC and cell proliferation was less elevated than that observed for cells from PP and the spleen. This is not surprising since the blood contains a small and labile pool of responsive lymphocytes (Westermann \& Pabst, 1990). However, in yoghurt-fed healthy human subjects, a higher activity of 2-5A synthetase in circulating BMC has been observed (Solis \& Lemonnier, 1991; Aattouri \& Lemonnier, 1997). Circulating $2-$ $5 \mathrm{~A}$ synthetase might be a more sensitive marker than an in vitro response. Moreover, the activity of 2-5 A synthetase can be induced by other interferons that were not measured in our present study.

The exposure of intestinal immune cells (PP may not be the exclusive site of action) to lactic-acid bacteria in vivo caused elevated in vitro proliferation and the production of IFN- $\gamma$ by addition of lactic-acid bacteria in the culture medium. As expected, Con A, a polyclonal activator of T cells, enhanced the production of IFN- $\gamma$ from incubated PP and spleen cells obtained from rats fed the milk-supplemented diet. Furthermore, this non-specific response was elevated by ingestion of lactic-acid bacteria, since IFN- $\gamma$ production doubled when the rats received the lactic-acid bacteria diet. These results demonstrate that feeding live lactic-acid bacteria contained in yoghurt exerts an immunoadjuvant effect on the host.

One major function of $\mathrm{T}$ helper cells is to provide signals necessary for activation, proliferation and differentiation of B cell. These effects depend on the cytokines being secreted at the time of $\mathrm{T}-\mathrm{B}$ cell interaction. Interferon- $\gamma$ is able to provide help to $\mathrm{B}$ cell in the production of the IgG2a isotype (Coffman et al. 1988). Interferon- $\gamma$ induces expression of class II of major histocompatibility complex determinants on various cell types such as macrophages and epithelial intestinal cells. Interferon- $\gamma$ treatment increases antigen presentation, induces activation of oxidative metabolism and inhibits the growth of intracellular parasites in macrophages (Murray, 1990). The known effects of IFN- $\gamma$ could explain or contribute to the observed effects of feeding lactic-acid bacteria or fermented milk on macrophage phagocytosis and production of IgG2a (Conge et al. 1980; Vesely et al. 1985; Perdigon et al. 1988). Previous studies have shown that laboratory animals fed diets supplemented with fermented milks are partially protected against Salmonella (Hitchins et al. 1985; De Simone et al. 1988; Perdigon et al. 1990). Moreover, pretreatment with IFN- $\gamma$ protects mice against $S$. typhimurium (Gould \& Sonnenfeld, 1987). Thus, it is suggested that the stimulation of IFN- $\gamma$ by consumption of live lactic-acid bacteria might contribute to protection against potentially harmful intestinal microflora and enteropathogenic micro-organisms.

In conclusion, this present study demonstrates that oral administration of lactic-acid bacteria stimulates the production of IFN- $\gamma$ in PP and spleen cells in healthy rats and elevates the proliferation of lymphocytes from PP, 
spleen and blood. This present study suggests that beneficial consequences might be obtained by an increase in resistance to some infections.

\section{Acknowledgements}

We thank the Centre Daniel Carasso for supplying bacterial preparations and EU STD3 program no. TS3-CT94-0282 for their financial support of this work. We are also grateful to M. Dubarry, M. Rautureau and J.F. Huneau for their very helpful suggestions and to R. Medeiros for his advice in editing the manuscript.

\section{References}

Aattouri N \& Lemonnier D (1997) Production of interferon induced by Streptococcus thermophilus: role of CD4+ and CD8+ lymphocytes. Journal of Nutritional Biochemistry 8, 25-31.

Bienestock J \& Befus AD (1980) Mucosal immunology. Immunology 41, 247-270.

Boyum A (1968) Isolation of mononuclear cell and granulocytes from human blood. Scandinavian Journal of Clinical and Laboratory Investigation 21, 77-89.

Cavaillon JM (1996) Le monde des Cytokines. In Les cytokines (The Cytokines), pp. 1-12 [JM Cavaillon, editor]. Paris: Masson.

Coffman RL, Seymour BW, Lebman DA, Hiraki DD, Christiansen JA, Shrader B, Cherwinski HM, Savelkoul HF, Finkelman FD, Bond MW \& Mosmann TR (1988) The role of helper T cell products in mouse B cell differentiation and isotype regulation. Immunological Reviews 102, 5-28.

Conge GA, Gouache P, Desormeau-Bedot A, Loisillier F \& Lemonnier D (1980) Effets comparés d'un régime enrichi en yoghourt vivant ou thermisé sur le système immunitaire de la souris (Comparative effects of a diet enriched in live or heated yoghurt on the immune system of the mouse). Reproduction Nutrition Développement 20, 929-938.

De Simone C, Jirillo E, Bianchi Savadori B, Baldinelli L, Tzantzoglou S, Difabio S, Grassi PP \& Vesely R (1988) Stimulation of host resistance by a diet supplemented with yoghurt. Advances in Biosciences 68, 279-284.

Gill HS, Rutherfurd KJ, Prasad J \& Gopal PK (2000) Enhancement of natural and acquired immunity by Lactobacillus rhamnosus (HN001) Lactopacillus acidophilus (HN017) and Bifidobacterium lactis (HN019). British Journal of Nutrition 83, 167-176.

Gould CL \& Sonnenfeld G (1987) Effect of treatment with interferon- $\gamma$ and concanavalin A on the course of infection of mice with Salmonella typhimurium strain LT-2. Journal of Interferon Research 7, 255-260.

Guy-Grand D, Griscelli C \& Vassalli P (1978) The mouse gut lymphocyte, a novel type of $\mathrm{T}$ cell. Nature, origin and traffic in mice normal and graft-versus-host conditions. Journal of Experimental Medicine 148, 1661-1677.

Hitchins AD, Wells P, McDonough EF \& Wong NP (1985) Amelioration of the adverse effect of gastrointestinal challenge with Salmonella enteritidis on weanling rats by a yoghurt diet. American Journal of Clininical Nutrition 41, 92-100.

Lefèvre F, Charley B \& La Bonnardière C (1996) Interferon gamma. In Les Cytokines (The Cytokines), pp. 1-12 [JM Cavaillon, editor]. Paris: Masson.

Meydani SN \& Ha WK (2000) Immunologic effect of yogurt. American Journal of Clinical Nutrition 71, 861-872.

Mowat AM (1987) The regulation of immune response to dietary protein antigens. Immunology Today 8, 93-98.

Murray HW (1990) Interferon gamma, cytokine-induced macrophage activation, and antimicrobial host defense. In vitro, in animal models, and in humans. Diagnostic Microbiology and Infectious Disease 13, 411-421.

Muscettola M, Massai L, Tanganelli C \& Grasso G (1994) Effects on lactobacilli on interferon production in young and aged mice. Annals of the New York Academy of Sciences 717, 226-232.

Nagata S, Mc Kenzie C, Pender SLF, Bajaj-Elliott M, Fairclough PD, Walker-Smith JA, Monteleone G \& MacDonald TT (2000) Human Peyer's patch $\mathrm{T}$ cells are sensitized to dietary antigen and display a $\mathrm{T}$ cell type 1 cytokine profile. Journal of Immunology 165, 5315-5321.

Nakanishi K, Hirose S, Yoshimoto T, Ishizashi H, Hiroishi K, Anaka T, Kono A, Miyasaka M \& Taniguchi T (1992) Role and regulation of interleukin (IL)-2 receptor $\alpha$ and $\beta$ chains in IL-2-driven B-cell growth. Proceedings of the National Academy of Science, USA 89, 3551-3555.

Neutra MR, Phillips TL, Mayer EL \& Fishkind M (1987) Transport of membrane-bound macromolecules by $\mathrm{M}$ cells in follicle-associated epithelium of rabbit Peyer's patches. Cell Tissue Research 247, 537-546.

Okutomi T, Inagawa H, Nishizawa T, Oshima H, Soma GI \& Mizuno DI (1990) Priming effect of orally administered muramyl dipeptide on induction of endogenous tumor necrosis factor. Journal of Biological Response Modifiers 9, 564-569.

Perdigon G, De Macias MEN, Alvarez S, Oliver G \& De Ruiz Holgado AAP (1988) Systemic augmentation of the immune response in mice by feeding fermented milk with Lactobacillus casei and Lactobacilus acidophilus. Immunology 63, 17-24.

Perdigon G, Nader De Macias M, Alvarez S, Oliver G \& Pesce De Ruiz AA (1990) Prevention of gastrointestinal infection using immunobiological methods with milk fermented with Lactobacillus casei and Lactobacillus acidophilus. Journal of Dairy Research 57, 255-264.

Potier de Courcy G, Durant G, Abraham G \& Gueguen L (1989) Recommandations sur les conditions d'alimentation des animaux de laboratoire (rats et souris) (Recommendations for feeding conditions of laboratory animals (rats and mice)). Sciences des Aliments 9, 209-217.

Ruedl C, Albin B, Wick G \& Wolf H (1993) Oral administration of bacterial immunomodulator enhance murine intestinal lamina propria and Peyer's patch lymphocyte traffic to lung: possible implications for infectious disease prophylaxis and therapy. International Immunology 5, 29-36.

Samuel CE (1991) Antiviral actions of interferon. Interferon regulated cellular protein and their surprisingly selective antiviral activities. Virology 183, 1-11.

Solis Pereyra B \& Lemonnier D (1991) Induction of 2-5A synthetase activity and interferon in humans by bacteria used in dairy products. European Cytokine Network 2, 137-140.

Solis Pereyra B \& Lemonnier D (1993) Induction of human cytokines by bacteria used in dairy foods. Nutrition Research 13, $1127-1140$.

Street NE \& Mosmann TR (1991) Functional diversity of T lymphocytes due to secretion of different cytokine patterns. FASEB Journal 5, 171-177.

Trinchieri G \& Perussia B (1985) Immune interferon: a pleiotropic lymphokine with multiple effects. Immunology Today $\mathbf{6}$, 131-136.

Vesely R, Negri R, Bianchi-Salvadori B, Lavezzari D \& De Simone C (1985) Influence of a diet additioned with yoghurt on the mouse immune system. Journal of Immunology and Immunopharmacology 5, 30-35.

Weiner HL (2000) Oral tolerance, an active immunologic process mediated by multiple mechanisms. The Journal of Clinical Investigation 106, 935-937.

Westermann J \& Pabst R (1990) Lymphocytes subsets in the blood: a diagnostic window on lymphoid system? Immunology Today 11, 406-410. 